\title{
Jansen-type Metaphyseal Chondrodysplasia: Analysis of PTH/PTH-related Protein Receptor Messenger RNA by the Reverse Transcriptase-Polymerase Chain Method
}

\author{
MASANORI MINAGAWA, KAZUO ARAKAWA*, SHIN TAKEUCHI**, KANSHI MINAMITANI, \\ TOSHIYUKI YASUDA, AND HIROO NIIMI
}

Department of Pediatrics, Chiba University School of Medicine, Chiba 260, *Division of Pediatrics, Suzaka General Hospital, Suzaka 382, and **Department of Pediatrics, School of Allied Medical Sciences Shinshu University, Matsumoto 390, Japan

\begin{abstract}
Jansen-type metaphyseal chondrodysplasia (JMC) has both delayed ossification in long bones and usually hypercalcemia. We report a Japanese male patient with JMC who presented with rachitic signs on radiographs, hypercalcemia $(13 \mathrm{mg} / \mathrm{d} l)$ and low \%TRP at age 3 months (mo). Hypercalcemia was treated from age 3 mo to 11 yr. Progressive widening, splaying and fragmentation of the metaphyses have been recognized on radiographs which resulted in shortened tubular bones and consequent short stature [107 $\mathrm{cm}(-6.5 \mathrm{SD})]$ at age $13 \mathrm{yr}$. Hypercalcemia tended to normalize, and $\%$ TRP became normal at age $13 \mathrm{yr}$. Repeated measurements of serum PTH and PTH-related protein (PTHrP) levels showed that they were low or normal in the face of hypercalcemia and high urine cAMP excretion, which led us to suspect constitutive activation of the PTH/PTHrP receptor. Direct sequencing of PTH/PTHrP receptor complementary DNA from skin fibroblast cells revealed a CAC to CGC transversion yielding a strictly conserved His ${ }^{223}$ to Arg substitution found in $90 \%$ of DNA fragment in the second transmembrane domain of the receptor. This mutation created a restriction site SphI (G/ CATG/C). Direct sequencing of genomic DNA and also restriction enzyme digestion revealed heterozygous transition. The mutation was absent in the parents with normal phenotype. We conclude that both dysplastic bone lesions and calcium homeostasis are age-dependent in JMC, and that the His ${ }^{223}$-Arg substitution is the same as that found in four Caucasian patients with a similar phenotype irrespective of the ethnic difference, and that the preferential expression of an abnormal allele of the PTH/PTHrP receptor mRNA in skin fibroblast despite heterogygotic transversion in the genomic DNA suggests the importance of allele expression.
\end{abstract}

Key words: Jansen-type metaphyseal chondrodysplasia, PTH/PTHrP receptor, Constitutive activation, Hypercalcemia

(Endocrine Journal 44: 493-499, 1997)

JANSEN-TYPE metaphyseal chondrodysplasia (JMC) is a rare form of short-limbed dwarfism caused by impaired metaphyseal ossification, giving rise to cyst-like areas in long bones [1, 2]. The condition is usually associated with

Received: January 6, 1997

Accepted: March 31, 1997

Correspondence to: Dr. Toshiyuki YASUDA, Department of Pediatrics, Chiba University School of Medicine, 1-8-1 Inohana, Chuo-ku, Chiba 260, Japan hypercalcemia despite low or normal concentrations of PTH and PTH-related protein (PTHrP) $[3,4]$. We first determined PTH-PTHrP levels in relation to urine cAMP excretion and serum and urine markers relating to bone resorption and formation in a Japanese patient with this condition. The PTH/PTHrP receptor belongs to a family of G protein-coupled receptors with signaling properties of both cAMP and $\mathrm{Ca}^{2+}[5,6]$. Since the patient's clinical data are compatible with the notion of activation of the PTH/PTHrP receptor without its 
ligand(s), we examined his $\mathrm{PTH} / \mathrm{PTHrP}$ receptor complementary DNA (cDNA) and identified His223Arg substitution in the cDNA. We also compared age-related changes in the widespread abnormalities with five other JMC patients, since just before the submission of this manuscript, Juppner et al. reported five JMC patients with the His 223-Arg or T410P substitution in the $\mathrm{PTH} / \mathrm{PTHrP}$ receptor gene $[7,8]$.

\section{Materials and Methods}

\section{Case}

A male infant was born to a healthy 34-year-old Japanese mother after an uncomplicated 42-week gestation. Both mother and father were of average height. His birth length and weight were $50 \mathrm{~cm}$ and $3.0 \mathrm{~kg}$, respectively. Shortly after birth, micrognathia and a high arched palate were recognized. Radiographs at age 1 month (mo) and 3 mo revealed rachitic rosary-like ribs, widened distal clavicles, and fraying and cupping of the bones (Fig. 1A - B). At 3 mo, he was hospitalized for evaluation of poor weight gain $(4450 \mathrm{~g})$. Blood chemistry studies revealed serum calcium levels of $13 \mathrm{mg} / \mathrm{d} l$ (normal value (n) for age: 8.8-10.5), phosphorus $3.6 \mathrm{mg} / \mathrm{d} l$ (n: 4.3-8.0), \% transport reabsorption of phosphate (\%TRP) 46\% (n: 85-97) and alkaline phosphatase 99.7 K.A. (n: 10-24). At that time, serum PTH levels were normal in two assay systems, and urine cAMP excretion tended to be high. Hypercalcemia was treated by oral phosphorus administration or calcitonin infusion from age $3 \mathrm{mo}$ to $11 \mathrm{yr}$. At age $9 \mathrm{yr}$, the serum PTHrP level was undetectable (less than $0.2 \mathrm{ng} /$ $\mathrm{ml}$ ) [8]. Progressive widening, splaying and fragmentation of the metaphyses, detected by radiography, resulted in shortened tubular bones and consequent short stature $107 \mathrm{~cm}(-6.5 \mathrm{SD})$ with an upper/lower segement ratio of 1.49 at age $13 \mathrm{yr}$ (Fig. 1C - D). The clinical data were serum calcium $10.5 \mathrm{mg} / \mathrm{d} l$ (n: 8.5-10.0), phosphorus 3.8 $\mathrm{mg} / \mathrm{d} l$ (n: 2.8-5.2), \%TRP $87.5 \%$ (n: 85-97), urine calcium excretion $0.14 \mathrm{mg} / \mathrm{d} l$ GF (n: 0.01-0.14), intact PTH $<5 \mathrm{pg} / \mathrm{ml}$ (n: 12-50: Nichols intact PTH assay kit), highly-sensitive mid-region PTH 60 pg/ $\mathrm{ml}$ (n: 180-520: Yamasa highly sensitive PTH assay kit), intact PTHrP $<1.1$ (Mitubishi chemical
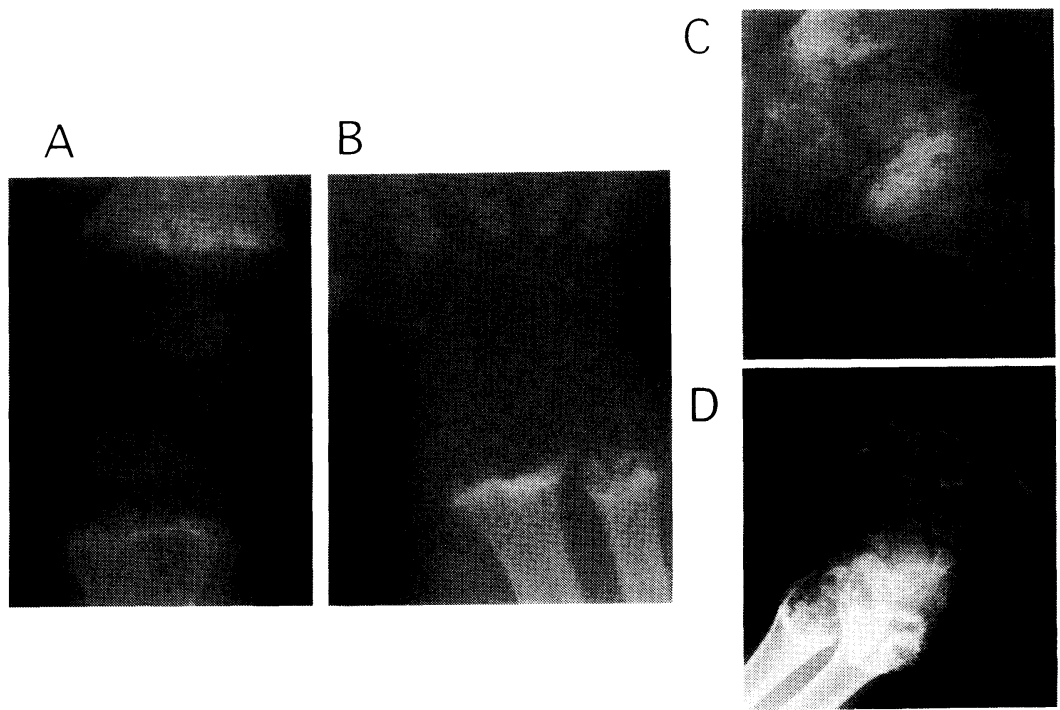

Fig. 1. Bone radiographs during infancy $(A \cdot B)$ and at age $13 \mathrm{yr}(C \cdot D)$. The right knee (A) and left hand at age 3 mo (B), right femoral neck (C) and left hand at age $13 \mathrm{yr}(\mathrm{D})$ are shown. At age $3 \mathrm{mo}$, there is irregularity of metapyseal ends, cupping and cortical lucencies. The metacarpals have a permeative lucency with poor definition of the cortex suggestive of subperiosteal resorption. At age $13 \mathrm{yr}$, the femur is very short with bulging proximal and distal ends. There are many cyst-like areas in the bone radiographs $(C \cdot D)$. 
industries Ltd. (n: < 1.1)) and c-terminal PTHrP 60 $\mathrm{pmol} / \mathrm{ml}$ (Daiichi Radio-isotope Laboratories Ltd. (n: 40-90)), and high nephrogenous cAMP 2.9 nmol/dlGF (n: 0.5-2.8: Yamasa cAMP RIA kit). Biochemical indices of bone formation were serum alkaline phosphatase 3038 (mainly bone specific) $\mathrm{IU} / \mathrm{ml}$ (n: 250-1000) and intact osteocalcin more than $100 \mathrm{ng} / \mathrm{ml}$ (Osteocalcin test Teijin ( $\mathrm{n}:<25)$ ), and those of bone resorption were serum tartrateresistant acid phosphatase $29 \mathrm{IU} / \mathrm{ml}$ (control adult value: 5-15), urine pyridinoline/creatinine (Crn) $550 \mathrm{pmol} / \mu \mathrm{molCrn}$ (HPLC: $\mathrm{n}: 50-350$ ) and urine deoxy-pyridinoline/Crn168 $\mathrm{pmol} / \mu$ molCrn (HPLC: n: 10-70). Serum 25OHD and 1,25- $(\mathrm{OH})_{2} \mathrm{D}$ levels were $42 \mathrm{ng} / \mathrm{ml}(\mathrm{n}: 5-40)$ and $60 \mathrm{pg} / \mathrm{ml}(\mathrm{n}$ : 30-80), respectively. Clinical data at age 14 yr were similar to the previous ones. Informed consent was obtained prior to the molecular study.

\section{$R T-P C R$}

Fibroblasts: Since initial attempts to obtain the patient's PTH/PTHrP receptor cDNA from Epstein-Barr virus-transformed lymphoblastoid cells were repeatedly unsuccessful, the patient's skin was obtained by punch biopsy. The biopsy was minced, and the fragments were cultured and maintained in Dulbecco's Modified Eagle's medium supplemented with $100 \mathrm{U} / \mathrm{ml}$ penicillin $\mathrm{G}, 50 \mu \mathrm{g} /$ $\mathrm{ml}$ streptomycin, $1 \mathrm{mmol}$ L-glutamine, and $10 \%$ FCS.

PTH/PTHrP receptor cDNA: PCR primers to obtain human $\mathrm{PTH} / \mathrm{PTHrP}$ receptor $\mathrm{CDNA}$ were prepared according to the published human $\mathrm{PTH} /$ PTHrP receptor cDNA nucleotide sequence [10] (Table 1). Each overlaps to cover the entire PTH/ PTHrP receptor coding sequence. Total RNA was extracted from skin fibroblasts $\left(10^{7}\right)$ with Isogen ${ }^{\mathrm{TM}}$ (Nippon gene, Tokyo), and quantified by measurement of optical density at $260 \mathrm{~nm}$. The fibroblast cDNA was obtained by reverse transcription of RNA with random hexamers as primers and 500 units of Superscript ${ }^{\mathrm{TM}}$ II (GibcoBRL, Gaithesburg, MD). One-tenth of the first strand synthesis reaction product was then amplified by PCR with either $2.5 \mathrm{U}$ of Taq DNA polymerase or $2.5 \mathrm{U}$ of Expand Taq DNA polymerase.

Table 1. Sequence and locations of oligonucleotide primers

\begin{tabular}{|c|c|}
\hline PTHR1 & CGGAGGGACGCGGCCCTAGGCGGTG (nt. 1-25) \\
\hline PTHR1R & CAGCACAGGATGTGGTCCCATTC (nt. 381-359) \\
\hline PTHR2 & ACAAGGAGGCACCCACTGGC (nt. 309-328) \\
\hline PTHR2R & CGAAGATGCTCACGGCGCGCAGCA (nt. 743-720) \\
\hline PTHR3 & GCCAACTACAGCGAGTGTGTCAA (nt. 521-523) \\
\hline PTHR3R & CTGAGAAGAAGGCCATGAAGATG (nt. 977-955) \\
\hline PTHR4 & CACCAACTACTACTGGATTCTGGTGG (nt. 907-932) \\
\hline PTHR4R & CTGGAAGGAGTTGAAGAGCA (nt. 1381-1362) \\
\hline PTHR5 & GACACACGGCAGCAGTACCG (nt. 1220-1239) \\
\hline PTHR5R & CCATCCACTATGTCAGCAGGTCCAGCCCCC (nt. 1849-1820) \\
\hline PTHRTM2 & GCGGCTGCACTGCACGCG (nt. 667-684) \\
\hline PTHRTM2R & GTAGCCGGCAGCGGCGGTGGC (nt. 862-842) \\
\hline \multicolumn{2}{|c|}{$\begin{array}{l}\text { PCR primers to obtain human PTH/PTHrP receptor cDNA were prepared according } \\
\text { to the published human PTH/PTHrP receptor cDNA nucleotide sequence [10]. } \\
\text { Nucleotide numbers are according to that paper. R denotes anti-sense primer. } \\
\text { Expected sizes of RT-PCR fragments are PTHR1/PTHR1R } 359 \mathrm{bp} \text {, PTHR2/PTHR2R } \\
435 \mathrm{bp} \text {, PTHR3/PTHR3R } 457 \mathrm{bp} \text {, PTHR4/PTHR4R } 475 \mathrm{bp} \text { and PTHR5/PTHR5R } \\
630 \mathrm{bp} \text {. Each overlaps to cover the entire PTH/PTHrP receptor coding sequence. } \\
\text { To clone the second transmembrane domain of the PTH/PTHrP receptor genomic } \\
\text { DNA, oligonucleotides in this region consisting of a single exon were prepared } \\
\text { (PTHRTM2/PTHRTM2R). The size of the expected PCR fragment is } 196 \mathrm{bp} \text {. }\end{array}$} \\
\hline
\end{tabular}




\section{PCR of the second transmembrane domain}

Genomic DNA was prepared with an Easy-DNA extraction kit (Invitrogen, San Diego, CA) from whole blood or an Isogen ${ }^{\mathrm{TM}}$ from skin fibroblasts. To clone the second transmembrane domain of the PTH/PTHrP receptor genomic DNA, oligonucleotides in this region consisting of a single exon were prepared: PTHRTM2 (nt. 667-684)/PTHRTM2R, (nt. 862-842) [10]. The size of the expected PCR fragment was $196 \mathrm{bp}$.

\section{Sequencing}

Amplified DNA fragments were purified with a QIA quick-gel extraction kit (Qiagen, Germany). Nucleotide sequencing was performed with either by a Sequenase ${ }^{\mathrm{TM}}$ version 2 sequencing kit (USB, Cleveland, Ohio) modified by adding $0.1 \%$ NP- 40 or Applied Biosystems' mode 373A automated sequencer with a Taq DyeDeoxy terminator cycle sequencing kit (Applied Biosystems Inc., Foster City, CA).

\section{Restriction enzyme digestion}

PCR fragments containing the second transmembrane domain [(PTHR3/PTHR3R (nt. 521-977: 457 bp)] and [PTHRTM2/PTHRTM2R (nt. 667-862: 196 bp)] were digested with SphI (G/ CATG/C) and resolved by electrophoresis on agarose gel.

\section{Results}

\section{DNA sequencing}

RT-PCR fragments of expected size were obtained covering the entire coding region of the $\mathrm{PTH} / \mathrm{PTHrP}$ cDNA. The entire extracellular domain, the membrane spanning domain and the intracellular domain were sequenced in both directions [10]. Only an a696g transition causing a H223R substitution in the second transmembrane domain of the PTH/PTHrP receptor was present in about $90 \%$ of patient's cDNA(PTHR3/PTHR3R) (Fig. 2A.C). Direct sequence analysis of genomic DNA containing the second membrane-spanning domain (nt. 667-862) revealed heterozygotic mutation $[\mathrm{C}(\mathrm{A} / \mathrm{G}) \mathrm{C}]$ in the patient genomic DNA, but the parents with the normal phenotype had a normal sequence in this region (Fig. 2B).

\section{Restriction enzyme digestion}

This mutation created a new restriction site $\mathrm{Sph}$ (G/CATG/C). The amplified cDNA (nt. 521-977) was almost completely digested by restriction endonuclease SphI (to give rise to $176 \mathrm{bp}$ and 281 bp fragments), and about one-tenth of the cDNA remained undigested (three RT-PCR fragments of the patient's cDNA were examined) (Fig. 2C). The patient's PCR genomic fragment containing second membrane-spanning domain (nt. 692-778) was heterozygotically digested (166 bp and $30 \mathrm{bp}$ ) (Fig. 2C).

\section{Discussion}

The hypercalcemia in this patient is not caused by hypersecretion of PTH or PTHrP, or by vitamin $\mathrm{D}$ intoxication. The relatively high urine cAMP excretion in the presence of hypercalcemia was consistent with hyperparathyroidism. These findings are compatible with the results of mutation(s) in the PTH/PTHrP receptor which constitutively activates the receptor to induce cAMP production without its ligand(s).

The mis-sense mutation at the junction between the PTH/PTHrP receptor's first intracellular loop and transmembrane helix 2 changing a histidine residue at position 223 to Arginine was the same as that reported by Schipani et al. in four Caucasian patients by direct sequencing of exon M2 (helix 2) genomic DNA $[7,8]$. But we found that the fibroblast PTH/PTHrP receptor cDNA predominantly expressed an abnormal allele despite the fact that examination of genomic DNA containing this region revealed a heterozygous nucleotide change in the exon M2 of the gene. This results suggests that it is importance which allele is predominantly expressed as a mRNA. The mechanism may be related to the difference in the rate of transcription, mRNA stability or the polymorphism in the regulatory element of the PTH/PTHrP receptor gene linked to the mutation or others. Since both unaffected parents were homozygous for the normal allele, and the patient's phenotype of wide-spread abnormalities suggests 


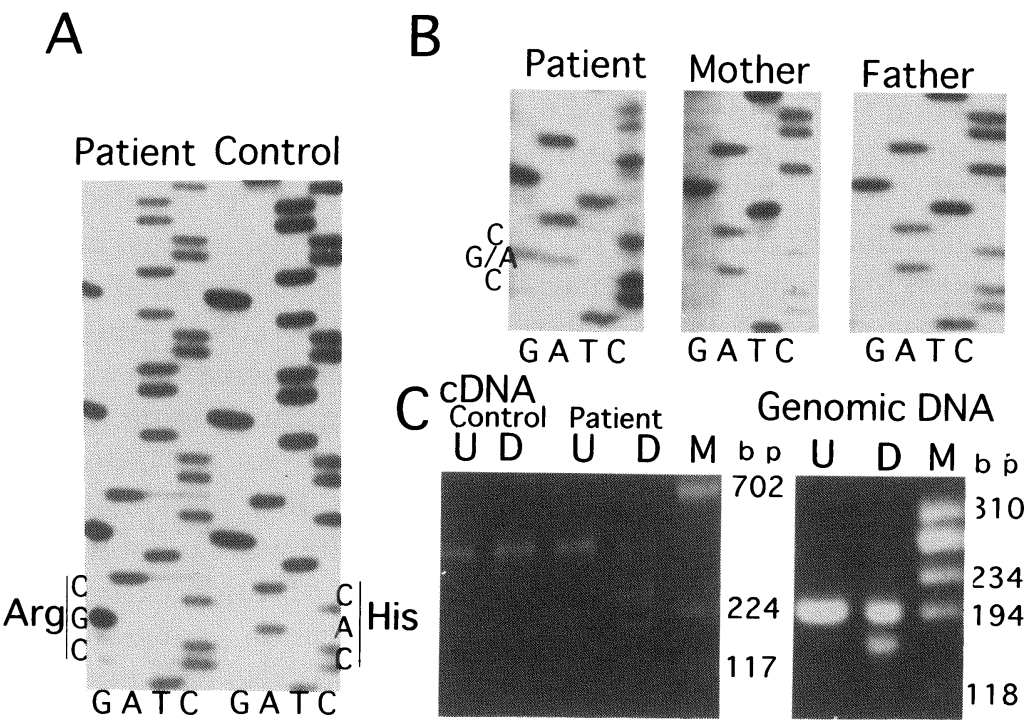

Fig. 2. Direct DNA sequences and restriction enzyme digestion of cDNA (PTHR3/PTHR3R: nt. 521-977) in the patient and the control and of genomic DNA (PTHRTM2/PTHRTM2R: nt. 667-843) in the patient, father and mother. PTHRTM2 was used as a sequence primer. The direct DNA sequence of cDNA(PTHR3/PTHR3R) of the patient revealed a CAC-CGC transversion to give rise to a strictly conserved (between spesies and receptor family) $\mathrm{His}^{223}$ to $\operatorname{Arg}(\mathrm{A})$, while the direct genomic DNA sequence revealed heterozygous substitution of A-G in the patient (B). The mother and father had a normal sequence in this region (B). In the case of the mutant allele, the expected sizes after SphI digeston were 176 bp and 281 bp in cDNA (PTHR3/PTHR3R: nt. 521977) and $166 \mathrm{bp}$ and $30 \mathrm{bp}$ (not visible) in genomic DNA (PTHRTM2/ PTHRTM2R: nt. 667-864) (C). The amplified cDNA (nt. 521-977) was almost completely digested with restriction endonuclease SphI, and about one-tenth of the cDNA remained undigested (C). The patient's PCR genomic fragment (nt. 692-778) was heterozygotically digested (C). D, digested; M, marker; U, undigested.

that the patient carries a new germ-line mutation or had developed a new somatic mutation early in development [7].

$\mathrm{His}^{223}\left(\mathrm{Ile}^{222}\right.$ ) in the human PTH/PTHrP receptor is strictly conserved between species $[5,10,11]$ and in GRF, calcitonin and secretin receptors which belong to one family of seven transmembrane $G$ protein-coupled receptors $[12,13]$, indicating the functional importance of this residue. Schipani et al. [7] reported a functional study showing that basal cAMP accumulation in COS-7 cells expressing this mutation was five times that in the wild type and there was reduced cAMP responsiveness to PTH or PTHrP, and that there was increased binding affinity for PTH or PTHrP, which contributed to the reduction in cell surface receptors. One additional mutaion T410P localized in the exon M6/7 was also reported in one patient with this condition, but the phenotype is surprisingly similar to that of H223R [8].

At birth or shortly after birth, this patient and another three Caucasian patients with the same mis-sense mutation reported by Kruse et al. [4, 7] and Schipani et al. $[8,14,15]$ had surprisingly normal birth length $(49-54 \mathrm{~cm})$ with rachitic signs on bone radiographs during infancy compared with the severe metaphyseal bone lesions and growth failure thereafter. Two reports indicate that JMC with the same mutation had normocalcemia at birth $[2,14]$. Unique conditions during the fetal period, that can partly account for the cause of the mild bone lesion and normocalcemia at birth, are 1) high serum calcium level induced by the transplacental supply of calcium and phosphorus, 2) the possibility of PTHrP or its fragment(s) in these processes at the placenta and 3) a high estrogen 
concentration in the blood, which is anabolic hormone in bone, and a high concentration of which inhibits interleukin 6 (IL6) and soluble IL6 receptor production, both of which are stimulators of bone resorption [17].

Recent findings suggest that PTHrP and PTH/ $\mathrm{PTHrP}$ receptors are related to integration of signals and communication between different zones of the epiphyseal plates. PTH/PTHrP receptor expression in growth plate cartilage is located mainly in the transitional zone between proliferated and hypertrophic chondrocytes, whereas PTHrP is widely expressed throughout the epiphysis, suggesting that cells in the transition are coordinated with the rate of chondrocyte maturation modulated by the $\mathrm{PTH} / \mathrm{PTHrP}$ receptor [18]. Indeed, in mice with an inactivated PTHrP gene, the reduced proliferation in the resting and proliferated zones and premature differentiation of chondrocytes in the epiphyseal plate lead to distorted chondrocyte columns and sporadic distribution of calcified cartilage, dwarfism and death shortly after birth [19]. The PTH/PTHrP receptor null mice exhibited the same phenotype, but most of them died prenataly [20]. In contrast, overexpression of PTHrP targeted to proliferating and prehypertrophic chondrocytes by means of mouse type II collagen promoter caused a marked delay in chondrocyte maturation and endochondral ossification [21]. These studies, which are usually performed with neonatal mice or mice in utero have provided some indications of how PTHrP and PTH/PTHrP receptor work in chondrogenesis, but it remains speculative whether the results are applicable to man. For this reason, careful examination of each patient with JMC contributes to an understanding how PTHrP and PTH/PTHrP receptor work in chondrogenesis in humans.

The increase in markers of osteoblastic bone formation such as alkaline phosphatase and intact osteocalcin, concomitant with a more or less comparable increase in markers of bone resorption, is striking considering the degree of urine cAMP excretion. As an index of urine phosphorus excretion, low phosphate reabsorption detected early in life was no longer detected at age $13 \mathrm{yr}$ in the face of high urine cAMP excretion, and hypercalcemia subsided with age. The latter finding was also noted in a recent report [8]. Since there are al least two distinct promoters in the $\mathrm{PTH} / \mathrm{PTHrP}$ receptor gene, an upstream promoter which is very active in the kidneys, and the other, downstream, promoter which is active in the bones and other organs, tissue specific usage of PTH/ PTHrP receptor promoter may be important in understanding the complex abnormalities which change with age in JMC [22].

\section{Acknowlegements}

This study was supported by a Grant-in-Aid for Scientific Research from the Ministry of Education, Science and Culture, Japan (No. 08670855) and a grant from The Foundation For Growth Science.

\section{References}

1. Jansen M (1934) Uber atypische chondrodystrophie (Achondropasie) und uber eine noch nicht beschriebene angeborene Wachstumsstorung des Knochensystems; Metaphysare Dysostosis. Z Orthrop 61: 253-286.

2. Cram PB, Fleming JL, Frame B, Fine G (1959) Metaphyseal chodrodysplasia of Jansen. J Bone Joint Surg 41: 951-959.

3. Hass WHD de, Boer W de, Grifion F (1969) A late follow-up of the first reported case. J Bone Joint Surg 51: 290-299.

4. Kruse K, Schutz C (1993) Calcium metabolism in the Jansen type metaphyseal dysplasia. Eur J Pediatr 152: 912-915.

5. Juppner $H$, Abou-Samra AB, Freeman $M$, Kong XF,
Schipani E, Richards J, Kolawski LF, Hock J, Potts JT, Kronenberg HM, Segre GV (1991) A G proteinlinked receptor for parathyroid hormone and parathyroid hormone-related peptide. Science 254: 1024-1027.

6. Spiegel AM. (1996) Mutations in G proteins and G protein-coupled receptors in endocrine disease. $J$ Clin Endocrinol Metab 81: 2434-2442.

7. Schipani E, Kruse K, Juppner H (1995) A constitutively active mutant PTH/PTHrP receptor in Jansen-type metaphyseal chondrodysplasia. Science 268: 98-100.

8. Schipani E, Langman CB, Parfitt AM, Jensen GS, Kikuchi S, Kooh SW, Cole WG, Juppner H (1996) Constitutively activated receptors for parathyroid 
hormone and parathyroid hormone-related peptide in Jansen's metaphyseal chondrodysplasia. New Engl J Med 335: 708-714.

9. Henderson JE, Shustik C, Kremer R, Rabbani SA, Hendy GN, Goltzman D (1990) Circulating concentrations of parathyroid hormone-like peptide in malignancy and in hyperparathyroidism. J Bone and Miner Res 5: 105-113.

10. Schipani E, Karga H, Karaplis AC, Hellman P, Xie LY, Potts JT Jr, Kronenberg HM, Segre G, AbouSamra AB, Juppner H (1993) Identical complementary deoxyribonucleic acids encode a human renal and bone parathyroid hormone (PTH)/PTH-related peptide receptor. Endocrinology 132: 2157-2165.

11. McCuaig KA, Clarke JC, White JH (1994) Molecular cloning of the gene encoding the mouse parathyroid hormone/parathyroid hormone-related peptide receptor. Proc Natl Acad Sci 91: 5051-5055.

12. Gaylin BB, Harrison JK, Zysk JK, Lyon CE, Lynch KR, Thorner MO (1993) Molecular cloning and expression of human anteriolar pituitary receptor for growth hormone-releasing hormone. Mol Endocrinol 7: 77-84.

13. Lin HY, Harris TL, Flannery MS, Aruffo A, Kaji EH, Gorn A, Kolakowski LF, Lodish HF, Goldring SR (1991) Expression cloning of an adenylate cyclase-coupled calcitonin receptor. Science 254: 1022-1024.

14. Silverhorn KG, Houston CS, Duncan BP (1992) Jansen's metaphyseal chondrodysplasia with longterm followup. Pediatr Radiol 22: 470-471.

15. Charrow J, Poznanski AK (1984) The Jansen type of metaphyseal chondrodysplasia: Condition of and review of radiographic manifestations in the newborn and adult. Am J Med Genet 18: 321-327.

16. Poli V, Balena R, Fattori E, Mrkatos A, Yamamoto
M, Tanaka H, Ciliberto G, Rodan GA, Constantini F (1994) Interleukin-6 deficient mice are protected from bone loss caused by estrogen depletion. EMBO J 13: 1189-1196.

17. Bismar H, Diel I, Ziegler R, Pfeilschifter J (1995) Increase cytokine secretion by human bone marrow cells after menopause or discontinuation of estrogen replacement. J Clin Endocrinol Metab 80: 3351-3355.

18. Amizuka N, Warshawsky $\mathrm{H}$, Henderson JE, Goltzman D, Karaplis AC (1994) Parathyroid hormone-related peptide-depleted mice show abnormal epiphyseal cartilage development and altered endochondral bone formation. J Cell Biol 126: 1611-1623.

19. Karaplis AC, Luz A, Glowacki J, Bronson RT, Tybulewicz VL, Kronenberg HM, Mulligan RC (1994) Lethal skeletal dysplasia from targeted disruption of the parathyroid hormone-related peptide gene. Gene Dev 8: 277-289.

20. Lanske B, Karaplis AC, Lee KK, Luz A, Vortkamp A, Pirro A, Karperien M, Defize LHK, Mulligan RC, Abou-Samra AB, Juppner $H$, Segre GV, Kronenberg HM (1996) PTH/PTHRP receptor in early development and Indian hedgehog-regulated bone growth. Science 273: 663-666.

21. Weir E, Philbrick W, Neff L, Amling M, Baron R, Broadus AE (1995) Targeted overexpression of parathyroid hormone-related peptide in chodrocytes causes skeletal dysplasia and delayed osteogenesis. J Bone Miner Res 10 (Suppl): s157 (Abst).

22. McCuaig K, Lee HS, Clarke JC, Assar H, Horsford J, White JH (1995) Parathyroid hormone/ parathyroid hormone-related peptide gene transcripts are expressed from tissue-specific and ubiquitous promoters. Nucleic Acids Research 23: 1948-1955. 